\title{
ANALISIS PUTUSAN HAKIM DALAM SENGKETA EKONOMI SYARIAH DI PENGADILAN AGAMA JAKARTA SELATAN TENTANG WANPRESTASI AKAD MURABAHAH (PUTUSAN NOMOR 3353/PDT.G/2018/PA.JS) \\ Oleh:
}

\author{
Farhan Asyhadi \\ farhanasyhadi@ubpkarawang.ac.id
}

\begin{abstract}
ABTRAKSI
Penelitian ini mengkaji "Analisis Putusan Hakim Dalam Sengketa Ekonomi Syariah Di Pengadilan Agama Jakarta Selatan Tentang Wanprestasi Akad Murabahah (Putusan Nomor 3353/PDT.G/2018/PA.JS)". Tujuan penelitian ini adalah bagaimana kewenangan Pengadilan Agama Jakarta Selatan dalam menyelesaikan sengketa ekonomi syariah pada putusan Pengadilan Agama Jakarta Selatan Nomor 3353/Pdt.G/2018/PA.JS. Penelitian ini adalah penelitian lapangan yang bersifat deskriptif kualitatif, dengan mengambil lokasi di Pengadilan Agama Jakarta Selatan. Pendekatan yang digunakan adalah pendekatan yuridis, teologis normatif, dan pendekatan sosiologis. Adapun pengumpulan data yang diperoleh di lapangan dengan teknik observasi, dan dokumentasi. Data yang dikumpulkan kemudian diolah dengan menggunakan analisis reduksi data, penyajian data dan penarikan kesimpulan. Berdasarkan hasil penelitian analisis putusan hakim mengabulkan gugatan Penggugat dengan dimana Tergugat telah melakukan wanprestasi/ingkar janji atas Akad Perjanjian Murabahah No. Al Murabahah Nomor. 001/ALIF/MRBH/10/2013 Tanggal 25 Oktober 2013, dan Lampiran Surat Nomor.022/ALIF/SPP/10/13 Tanggal 25 Oktober 2013. (Selanjutnya disebut Akad Murabahah No.001/2013) dan menghukum terhadapnya untuk membayar sisa kewajiban hutang murabahah yang harus dibayar oleh Tergugat sebesar Rp. 3.499.700.000,- (tiga miliar empat ratus sembilan puluh sembilan juta tujuh ratus ribu rupiah) kepada Penggugat.
\end{abstract}

\section{Keywords: Ekonomi Syariah, Wanprestasi, Murabahah}

\section{A. PENDAHULUAN}

Pasca amandemen Undang-Undang Nomor 7 Tahun 1989 tentang Pengadilan Agama yang merupakan perubahan atas Undang-Undang Nomor 3 Tahun 2006, Mahkamah Agung mengerluarkan PERMA Nomor 02 Tahun 2008 Tentang Kompilasi Hukum Ekonomi Syariah ${ }^{2}$, memutuskan hakim Pengadilan Agama memiliki tugas baru yaitu perluasan kewenangan untuk menangani sengketa ekonomi syariah, tidak dibatasi hanya bidang sengketa perbankan syariah namun termasuk bidang ekonomi syariah lain diantaranya Lembaga Keuangan Mikro syariah, Asuransi Syariah, Reasuransi Syariah,

\footnotetext{
${ }^{1}$ Dosen Ilmu Hukum Fakultas Hukum Universitas Buana Perjuangan Karawang.

2 Mahkamah Agung RI Direktorat Jendaral Badan Peradilan Agama, Pedoman Pelaksanaan Tugas dan Administrasi Badan Peradilan Agama Buku II, 2013, h. 169-170
} 
Reksadana syariah, Obligasi syariah dan surat berharga berjangka menengah syariah, Sekuritas Syariah, Pembiayaan syariah, Pegadaian Syariah, Dana Pensiun Lembaga Keuangan Syariah, dan Bisnis Syariah ${ }^{3}$, sebagaimana penjelasan Pasal 49 huruf I dampak perluasan kewenangan itu membawa konsekuensi sebagai suatu tantangan tersendiri terutama bagi hakim Pengadilan Agama.

Dasar dari sebuah ekonomi adalah merupakan kegiatan yang tidak terlepas dari harta dan benda ${ }^{4}$. Dikatakan kegiatan ekonomi apabila ada sebuah transaksi ekonomi antara satu pihak dengan pihak yang lain, yang terkadang transaksi tersebut menimbulkan sebuah sengketa. Sengketa dalam Kamus Besar Bahasa Indonesia adalah segala sesuatu yang menyebabkan perbedaan pendapat, pertikaian atau perbantahan ${ }^{5}$. Oleh karena itu kata lain dari sengketa adalah konflik, secara bahasa kedua kata tersebut mengandung arti suatu peristiwa yang menggambarkan tentang adanya perbedaan atau benturan kepentingan antara dua pihak atau lebih. Konflik adalah keadaan dimana apabila dua pihak atau lebih dihadapkan pada perbedaan kepentingan berkembang menjadi sebuah sengketa (wanprestasi) apabila pihak yang merasa dirugikan telah menyatakan rasa tidak puas atau keprihatinannya, baik secara langsung kepada pihak yang dianggap sebagai penyebab kerugian atau kepada pihak lain.

Adapun salah satu sengketa wanprestasi yang telah sampai ke Pengadilan Agama Jakarta Selatan adalah sengketa yang terjadi antara salah satu lembaga keuangan syariah dengan salah satu pihak nasabah lembaga tersebut. Sengketa wanprestasi tersebut telah berkekuatan hukum tetap dengan putusan nomor 3353/Pdt.G/2018/PA.JS.

Secara garis besar sengketa yang terjadi antara PT. Al-Ijarah Indonesia Finance yang berkedudukan di Menara Palma Lantai 25 Jl. HR. Rasunja Said Blok X2 Kav.6, Kuningan Jakarta Selatan dengan salah satu nasabahnya Abdul Haris Gani, S.Sos.,M.Si. PT. Al-Ijarah Indonesia Finance (Penggugat) yang dimaksud menggugat nasabah bank Abdul Haris Gani, S.Sos.,M.Si

\footnotetext{
3 Jaih Mubarok, Hukum Ekonomi Syariah Akad Mudharabah (Bandung: fokusmedia, 2013).

${ }^{4}$ Juhaya S Pradja, Ekonomi Syariah (Bogor: Pustaka Setia, 2012).

5 Departemen Pendidikan dan Kebudayaam, Kamus Besar Bahasa Indonesia (Jakarta: Balai Pustaka, 1990).
} 
(Tergugat) atas gugatan wanprestasi. Sebagaimana terlampir dalam putusan Pengadilan Agama Jakarta Selatan nomor 3353/Pdt.G/2018/PA.JS., bentuk wanprestasi yang dimaksud adalah Tergugat tidak sanggup memenuhi kewajiban membayar dan kewajiban-kewajiban lainnya dalam akad pembiayaan Murabahah Nomor : 001/ALIF/MRBH/10/2013 Tanggal 25 Oktober 2013, dan Lampiran Surat Nomor.022/ALIF/SPP/10/13 Tanggal 25 Oktober 2013. (Selanjutnya disebut Akad Murabahah No.001/2013) Maka atas keterangan tersebut, PT. Al-Ijarah Indonesia Finance (Penggugat) yang telah dirugikan mengajukan gugatan ke pengadadilan Agama Jakarta Selatan.

Berdasarkan uraian permasalahan yang terjadi diatas, maka penulis ingin mengetahui secara lebih jelas mengenai penyelesaian sengketa wanprestasi melalui putusan Pengadilan Agama dengan judul "Analisis Putusan Hakim Dalam Sengketa Ekonomi Syariah Di Pengadilan Agama Jakarta Selatan Tentang Wanprestasi Akad Murabahah (Putusan Nomor 3353/Pdt.G/2018/PA.JS)"

\section{B. PERMASALAHAN}

Berdasarkan latar belakang di atas, permasalahan yang penulis rumuskan adalah bagaimana kewenangan Pengadilan Agama dan penyelesaian sengketa ekonomi syariah pada putusan Pengadilan Agama Jakarta Selatan pada perkara Nomor 3353/Pdt.G/2018/PA.JS ?

\section{METODOLOGI PENELITIAN}

Penelitian ini adalah penelitian lapangan yang bersifat deskriptif kualitatif, yang berlokasi di Pengadilan Agama Karawang. Adapun pendekatang yang digunakan adalah pendekatan yuridis-empiris yaitu menganalisis suatu permasalahan dengan menggunakan peraturan perundang-undangan yang kemudian dielaborasikan dengan data-data empiris di lapangan. Data yang telah dikumpulkan kemudian diolah dengan menggunakan analisis reduksi data, penyajian data adan penarikan kesimpulan. 


\section{HASIL PENELITIAN DAN PEMBAHASAN}

\section{Kewenangan Pengadilan Agama Terhadap Penyelesaian}

\section{Sengketa Ekonomi Syariah}

Pasal 49 Undang-Undang Nomor 3 Tahun 2006 Tentang Peradilan Agama secara jelas memberikan kompetensi kepada peradilan agama untuk mengadili perkara ekonomi syari'ah, termasuk perbankan syariah sebagai suatu kompetensi absolut. Alasan bahwa pengadilan dalam lingkungan peradilan agama belum familiair dalam menyelesaikan perkara perbankan, bukan menjadi suatu alasan yang logis untuk mereduksi kewenangan mengadili dalam perkara perbankan syariah.

Kewenangan mengadili perkara ekonomi syariah menjadi dualisme penyelesaiaan terutama dalam konteks perbankan syariah yaitu Pengadilan Agama dengan Pengadilan Agama ketika para pembuat akad mengacu pada proses peradilan dalam lingkup pengadilan Agama dengan dasar Pasal 55 ayat (2) Undang-Undang Nomor 21 Tahun 2008 yang menyebutkan ketika adanya sengketa maka diselesaikan sesuai dengan akad perjanjian syariahnya.

Polemik tersebut menuntut Mahkamah Agung untuk mempertegas dan menyelesaikan dualisme penyelesaiaan perkara dalam lingkup litigasi tersebut. Sehingga pada tahun 2008 ketika polemik itu muncul Mahkamah Agung memutuskan dalam Surat Edaran Mahkamah Agung Nomor 8 Tahun 2008 tentang eksekusi Putusan Badan Arbitrase Syariah Nasional terhadap sengketa ekonomi syari'ah. Berdasarkan Surat Edaran Mahkamah Agung No. 8 tahun 2008 tersebut mempertegas keberadaan pengadilan agama dalam eksekusi putusan Badan Arbitrase Syari'ah Nasional sekaligus menangani dan memutus perkara ekonomi syariah.

Sehingga Kompetensi pengadilan Agama untuk memutus perkara ekonomi syari'ah menjadi kompetensi absolute karena didukung dengan dasar hukum Undang- Undang Nomor 3 Tahun 2006 tentang Pengadilan Agama Pasal 49 Ayat (2), Undang- Undang Nomor 21 Tahun 2008 tentang Perbankan syari'ah Pasal 55, dan Surat Edaran Mahkamah Agung Nomor 8 Tahun 2008 Tentang eksekusi Putusan Badan Arbitrase Syari'ah Nasional. 
Kompetensi absolut yang masuk di Peradilan Agama Jakarta Selatan, adalah sebagai berikut Pengadilan Agama bertugas dan berwenang memeriks, memutus, dan menyelesaikan perkara-perkara ditingkat pertama antara orang-orang yang beragama Islam di bidang: Cerai Talak, Cerai Gugat, Poligami, Adopsi, Pengesahan Nikah, Ijin Kawin, Dispensasi Nikah, Fasakh, Rujuk, Syiqoh, Kewarisan, Wasiat, Hibah, Wakaf, Zakat, Infaq, Sedekah, dan Ekonomi Syari’ah.

\section{Penyelesaian sengketa ekonomi syariah di Pengadilan Agama Jakarta}

\section{Selatan}

Pengajuan gugatan sengketa wanprestasi telah masuk di Pengadilan Agama Jakarta Selatan dalam register perkara Nomor 3353/Pdt.G/2018/PA.JS tanggal 20 September 2018 dengan duduk perkara sebagai berikut :

1. Bahwa Penggugat dan Tergugat telah membuat Perjanjian Pembiayaan Al Murabahah Nomor. 001/ALIF/MRBH/10/2013 Tanggal 25 Oktober 2013, dan Lampiran Surat Nomor.022/ALIF/SPP/10/13 Tanggal 25 Oktober 2013. (Selanjutnya disebut Akad Murabahah No.001/2013), dengan rincian sebagai berikut :

Peruntukan

Plafond Pembiayaan

Harga Beli

Margin

Harga Jual

Jangka Waktu
: Pembelian 601.250 Liter Solar Industri.

: Rp2.999.700.000,-(dua miliar sembilan ratus sembilan puluh sembilan juta tujuh ratus ribu rupiah) Rp2.999.700.000,-(dua miliar sembilan ratus sembilan puluh sembilan juta tujuh ratus ribu rupiah)

: Rp900.000.000,- (sembilan ratus juta rupiah)

: Rp3.899.700.000,- (tiga miliar delapan ratus sembilan puluh sembilan juta tujuh ratus ribu rupiah)

: 36 (tiga puluh enam) bulan. 
Total kewajiban/hutang murabahah yang harus dibayar oleh Tergugat adalah Rp3.899.700.000,- (tiga miliar delapan ratus sembilan puluh sembilan juta tujuh ratus ribu rupiah)

2. Bahwa pada tanggal 29 Oktober 2013, Tergugat juga telah menandatangani surat Tanda Terima Pembelian Barang, dengan perincian sebagai berikut:

\begin{tabular}{|l|l|l|l|}
\hline No & Nama Barang & Jumlah & Harga Total \\
\hline 1 & $\begin{array}{l}\text { Solar Industri (HSD) } \\
\text { milik PT Pratama } \\
\text { Putratunggal }\end{array}$ & $\begin{array}{l}\text { liter } \\
\text { milik CV.ARS Pratama }\end{array}$ & $\begin{array}{l}\text { Rp 3.899.700.000,- } \\
\text { (tiga miliar delapan } \\
\text { ratus sembilan puluh } \\
\text { sembilan juta tuju ratus } \\
\text { ribu rupiah). }\end{array}$ \\
\hline 2 & $\begin{array}{l}\text { Solar Industri (HSD) } \\
\text { meno0 liter }\end{array}$ & & \\
\hline
\end{tabular}

3. Bahwa untuk menjamin pembayaran kembali Fasilitas Pembiayaan yang telah diterima oleh Tergugat, Pada Pasal 7 Akad Murabahah No.001/2013, telah disepakati jaminan-jaminan sebagai berikut :

3.1 Sebidang tanah Sertipikat Hak Milik Nomor. 20116/Tamangapa, berdasar Surat Ukur Nomor. 00109/2002 Tanggal 15 Juli 2002, seluas 800M2, berada di Provinsi Sulawesi Selatan, Kota Makassar, Kecamatan Manggala, Desa Tamanggapa. Tercatat atas nama Abdul Haris Gani.

3.2 Sebidang tanah Sertipikat Hak Milik Nomor. 20147/Tamangapa, berdasar Surat Ukur Nomor. 00108/2002 Tanggal 16 Juli 2002, seluas 450M2, berada di Provinsi Sulawesi Selatan, Kota Makassar, Kecamatan Manggala, Desa Tamanggapa. Tercatat atas nama Abdul Haris Gani.

3.3 Sebidang tanah Sertipikat Hak Milik Nomor. 20148/Tamangapa, berdasar Surat Ukur Nomor. 00106/2002 Tanggal 15 Juli 2002, seluas $1.003 \mathrm{M}^{2}$, berada di Provinsi Sulawesi Selatan, Kota Makassar, Kecamatan Manggala, Desa Tamanggapa. Tercatat atas nama Abdul Haris Gani.

3.4 Sebidang tanah dan bangunan rumah batu, Sertipikat Hak Guna Bangunan Nomor. 1148/Antang, berdasar Surat Ukur Nomor. 1823/1988 Tanggal 13 Mei 1988 , seluas $143 \mathrm{M}^{2}$, berada di Provinsi Sulawesi Selatan, Kota Ujung Pandang, Kecamatan 
Panakkukang, Desa Antang. Tercatat atas nama Andriani Nur Sarjana Sastra.

3.5 Sebidang tanah Sertipikat Hak Milik Nomor. 447/Coppo, berdasar Surat Ukur Nomor. 19/2004 Tanggal 18 Oktober 2004, seluas $600 \mathrm{M}^{2}$, berada di Provinsi Sulawesi Selatan, Kabupaten Barru.

4. Bahwa selain jaminan sebagaimana pada Pasal 7 Akad Murabahah No.001/2013, Tergugat juga telah menyerahkan obyek jaminan tambahan sebagai berikut :

4.1 Sebidang tanah Sertipikat Hak Milik Nomor. 01078/Coppo, berdasar Surat Ukur Nomor. 00163/Coppo/2012 Tanggal 24 April 2012, seluas 535M ${ }^{2}$, berada di Provinsi Sulawesi Selatan, Kabupaten Barru, Kecamatan Barru, Desa Coppo. Tercatat atas nama Hj.Andriani Nur., S.S.

4.2 Sebidang tanah Sertipikat Hak Milik Nomor. 01079/Coppo, berdasar Surat Ukur Nomor. 00161/Coppo/2012 Tanggal 19 April 2012, seluas $980 \mathrm{M}^{2}$, berada di Provinsi Sulawesi Selatan, Kabupaten Barru, Kecamatan Barru, Desa Coppo. Tercatat atas nama Hajjah Andriani Nur., S.S.

5. Bahwa dari Total hutang Murabahah sebesar Rp 3.899.700.000,- (tiga miliar delapan ratus sembilan puluh sembilan juta tuju ratus ribu rupiah), akan tetapi terhitung dari bulan Nopember 2013 sampai dengan bulan Januari 2015 Tergugat baru membayar sebesar Rp 400.000.000, (empat ratus juta rupiah). Sehingga total hutang Murabahah masih sebesar Rp. 3.499.700.000,- (tiga miliar empat ratus sembilan puluh sembilan juta tujuh ratus ribu rupiah).

6. Bahwa terhadap tindakan Tergugat yang tidak melaksanakan kewajibannya yang diatur pada Akad Murabahah No.001/2013, Penggugat melalui Kuasa Hukum telah mengirimkan surat teguran kepada Tergugat, sebagai berikut :

1) Surat Teguran Nomor. 007/DSP/I/2018, Perihal : Somasi Perbuatan Cidera Janji (Wanprestasi) atas Perjanjian Pembiayaan Murabahah Nomor. 001/ALIF/MRBH/10/2013 tanggal 25 Oktober 2013. 
2) Surat Teguran Nomor.13/DSP/I/2018, Perihal : Somasi II Perbuatan Cidera Janji (Wanprestasi) atas Perjanjian Pembiayaan Murabahah Nomor. 001/ALIF/MRBH/10/2013 tanggal 25 Oktober 2013.

7. Bahwa pada Gugatan a quo, Penggugat menarik Turut Tergugat dengan alasan bahwa Turut Tergugat telah turut menandatangani Surat Nomor.022/ALIF/SPP/10/13 Tanggal 25 Oktober 2013, dimana surat tersebut berdasarkan Pasal 1 Ayat (10) dan Pasal 8 Ayat (6) Akad Murabahah No.001/2013 merupakan lampiran atau bagian yang tidak terpisahkan dari Akad Murabahah No.001/2013.

8. Bahwa sekalipun Penggugat memberikan Surat Teguran kepada Tergugat, akan tetapi Tergugat tetap tidak menghiraukan teguran dari Penggugat dan tetap tidak menjalankan kewajibannya membayarkan angsuran atau melunasi sisa kewajiban kepada Penggugat. Oleh karenanya dengan sangat terpaksa gugatan a quo diajukan kepada Yang Mulia Ketua Pengadilan Agama Jakarta Selatan agar mendapatkan keadilan dan kepastian hukum, guna mempertanggung jawabkan dana umat masyarakat yang dikelola oleh Penggugat.

9. Bahwa selain Tergugat tidak melakukan pembayaran sesuai dengan isi Akad Murabahah NO.001/2013, Tergugat juga mempunyai itikad tidak baik karena ternyata tidak bersedia untuk menandatangani dokumen-dokumen pengikatan Hak Tanggungan atas obyek jaminan yang telah diterima oleh Penggugat. Oleh karenanya seluruh obyek jaminan hingga saat ini belum diikat dengan Hak Tanggungan.

10. Bahwa berdasarkan pada Pasal 36 Peraturan Mahkamah Agung RI Nomor. 02 Tahun 2008 Tentang Kompilasi Hukum Ekonomi Syariah (PERMA No.2/2008 KHES) tindakan yang dilakukan oleh Tergugat cukup jelas dan berdasar untuk dapat dikategorikan sebagai perbuatan cidera janji (wanprestasi).

\section{Putusan hukumnya}

Dalam pertimbangan hukum yang ada dalam putusan Nomor 3353/Pdt.G/2018/PA.JS. ini penulis setuju dengan apa yang dijadikan landasan Hakim dalam membuat keputusan tentang penyelesaian sengketa wanprestasi pada Akad Perjanjian Murabahah Al Murabahah Nomor. 
001/ALIF/MRBH/10/2013 Tanggal 25 Oktober 2013, dan Lampiran Surat Nomor.022/ALIF/SPP/10/13 Tanggal 25 Oktober 2013. (Selanjutnya disebut Akad Murabahah No.001/2013) ${ }^{6}$. Perjanjian Pembiayaan yang dibuat oleh Penggugat dengan Tergugat diperuntukkan untuk pembelian 601.250 liter solar industri pada plafon pembiayaan dan harga beli sebesar Rp. 2.999.700.000,(dua milyar sembilan ratus sembilan puluh sembilan juta tujuh ratus ribu rupiah), dengan margin sebesar Rp. 900.000.000,- (sembilan ratus juta rupiah), dimana penerapan harga jual sebesar Rp. 3.899.700.000,- (tiga milyar delapan ratus sembilan puluh sembilan juta tujuh ratus ribu rupiah), dalam jangka waktu 36 (tiga puluh enam) bulan. Akan tetapi terhitung dari Nopember 2013 sampai dengan bulan Januari 2015 Tergugat baru membayar sebesar Rp. 400.000.000,(empat ratus juta rupiah). Tergugat tidak lagi membayar kewajiban angsuran kepada Penggugat setidak-tidaknya sejak diberikannya surat teguran pertama tanggal 18 Januari 2018 hingga gugatan a quo diajukan sisa hutang murabahah sebesar Rp. 3.499.700.000,- (tiga milyar empat ratus sembilan puluh sembulan juta tujuh ratus ribu rupiah).

Disini Hakim melihat terlebih dahulu fakta-fakta yang ada sebelum membuat putusan tersebut. Hal yang menguatkan keyakinan Hakim dalam memutus perkara bahwa Tergugat dianggap melakukan wanprestasi/ingkar janji karena telah melalaikan kewajibannya/tidak pernah lagi melunasi pokok pembiayaan dan margin keuntungan kepada Penggugat, pembuktiannya dapat dinilai dari alat-alat bukti berupa surat yang diajukan oleh Penggugat seluruhnya yang diakui/dibenarkan oleh pihak Tergugat maka tidak perlu dibuktikan. Sama halnya dengan dalil gugatan Penggugat harus dibuktikan dan dalam hal ini telah terbukti bahwa Tergugat telah melakukan wanprestasi, oleh karena itu Penggugat memiliki legal standing untuk mengajukan gugatan pembayaran sisa hutang sebagaimana diatur dalam Pasal 49 huruf (i) Undang

-Undang Nomor 3 Tahun 2006 Tentang Perubahan atas Undang-Undang Nomor 7 Tahun 1989 Tentang Peradilan Agama jo. Putusan Mahkamah Konstitusi Nomor 93/PUU-X/2012 tanggal 29 Agustus 2013;

Tergugat dianggap telah melakukan wanprestasi terhadap akad yang

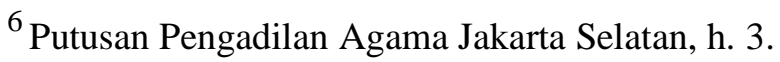


ditandatanganinya karena tidak melaksanakan sesuai prosedur pelaksanaan pembiayaan murabahah yaitu berupa jangka waktu pelunasan yang melebihi ketentuan dalam akad dan jumlah cicilan yang tidak sesuai dengan ketentuan akad. Prosedur pelaksanaan harus ditempuh agar fasilitas pembiayaan murabahah tersebut sah. Berdasarkan pada hasil penelitian penulis, karena Tergugat telah melakukan wanprestasi maka menurut Pasal 1243 KUH Perdata dibebani ganti kerugian berupa, "penggantian biaya, kerugian dan bunga karena tak dipenuhinya suatu perikatan mulai diwajibkan apabila debitur setelah dinyatakan lalai memenuhi perikatannya, tetap melalaikannya, atau sesuatu yang harus diberikan atau diperbuatnya hanya dapat diberikan atau diperbuat dalam tenggang waktu yang telah melampaukannya".

Adapun yang menjadi dasar hukum atas putusan yang diambil di persidangan adalah sebagai berikut: Dalam putusan hakim mengabulkan gugatan Penggugat dengan dimana Tergugat telah melakukan wanprestasi/ingkar janji atas Akad Perjanjian Murabahah No. Al Murabahah Nomor. 001/ALIF/MRBH/10/2013 Tanggal 25 Oktober 2013, dan Lampiran Surat Nomor.022/ALIF/SPP/10/13 Tanggal 25 Oktober 2013. (Selanjutnya disebut Akad Murabahah No.001/2013) dan menghukum terhadapnya untuk membayar sisa kewajiban hutang murabahah yang harus dibayar oleh Tergugat sebesar Rp. 3.499.700.000,- (tiga miliar empat ratus sembilan puluh sembilan juta tujuh ratus ribu rupiah) kepada Penggugat. Menyatakan, Tergugat yang telah dipanggil secara resmi dan patut untuk datang menghadap di persidangan, tidak hadir, Mengabulkan gugatan Penggugat sebagian dengan verstek, dan apabila putusan Pengadilan Agama Jakarta Selatan Nomor 3353/Pdt.G/2018/PA.JS,

Menghukum Penggugat, Tergugat dan Turut Tergugat untuk membayar biaya perkara secara tanggung renteng yang hingga kini dihitung sebesar Rp. 871.000,- (delapan ratus tujuh puluh satu ribu rupiah);

\section{E. PENUTUP}

Dari hasil penelitian dan pembahasan yang telah penulis lakukan, sebagai jawaban dari permasalahan yang menjadi objek penelitian ini, dapat diambil beberapa kesimpulan sebagai berikut :

1. Penyelesaian perkara ekonomi syari'ah di lingkungan peradilan agama secara 
prosedural akan dilakukan sesuai dengan ketentuan hukum acara perdata sebagaimana yang berlaku di lingkungan peradilan umum. Hal ini tidak lain merupakan konsekuensi dari ketentuan Pasal 54 UU No. 7 Tahun 1989 sebagaimana telah diubah dengan UU No. 3 Tahun 2006. Namun meskipun demikian, secara substansial arah dan tujuan penyelesaian sengketa ekonomi syari'ah di peradilan agama jelas tidak sama persis dengan penyelesaian sengketa ekonomi konvensional di peradilan umum.

2. Penyelesaian sengketa ekonomi syariah melalui gugatan ke Pengadilan Agama Jakarta Selatan dengan duduk perkara Nomor 3353/Pdt.G/2018/PA.JS, dilakukan dengan mengajukan pendaftaran gugatan ekonomi syariah kemudian memanggil para pihak dilanjutkan dengan mediasi setelah itu mengajukan pembuktian dan berakhir dengan putusan di persidangan dengan dalil putusan mengabulkan sebagian gugatan Penggugat sesuai dengan kontrak/perjanjian yang telah disepakati oleh para pihak berperkara yaitu tentang pembiayaan murabahah nomor : 001/ALIF/MRBH/10/2013 pada tanggal 25 Oktober 2013.

3. Perjanjian Pembiayaan yang dibuat oleh Penggugat dengan Tergugat diperuntukkan untuk pembelian 601.250 liter solar industri pada plafon pembiayaan dan harga beli sebesar Rp. 2.999.700.000,- (dua milyar sembilan ratus sembilan puluh sembilan juta tujuh ratus ribu rupiah), dengan margin sebesar Rp. 900.000.000,- (sembilan ratus juta rupiah), dimana penerapan harga jual sebesar Rp. 3.899.700.000,- (tiga milyar delapan ratus sembilan puluh sembilan juta tujuh ratus ribu rupiah), dalam jangka waktu 36 (tiga puluh enam) bulan.

4. Bahwa Terhitung sejak bulan Nopember 2013 sampai dengan bulan Januari 2015 Tergugat baru membayar sebesar Rp. 400.000.000,- (empat ratus juta rupiah). Tergugat tidak lagi membayar kewajiban angsuran dan tidak lagi adanya iktikad baik kepada Penggugat setidak-tidaknya sejak diberikannya surat teguran Perbuatan Ingkar Janji Keterlambatan Angsuran (Somasi I) tanggal 18 Januari 2018 kemudian surat teguran Perbuatan Ingkar Janji Keterlambatan Angsuran (Somasi II) hingga gugatan a quo diajukan sisa hutang murabahah sebesar Rp. 3.499.700.000,- (tiga milyar empat ratus sembilan puluh sembulan juta tujuh ratus ribu rupiah).

5. Menghukum Tergugat untuk membayar sisa kewajiban hutang murabahah yang harus dibayar oleh Tergugat sebesar Rp. 3.499.700.000,- (tiga miliar 
empat ratus sembilan puluh sembilan juta tujuh ratus ribu rupiah) kepada Penggugat langsung seketika setelah putusan mempunyai kekuatan hukum tetap;

\section{Saran}

Berdasarkan beberapa kesimpulan yang dikemukakan di atas, perlu disarankan halhal sebagai berikut :

1. Bagi pihak yang menangani perkara gugatan wanprestasi yakni hakim sebaiknya untuk lebih berhati-hati dalam menyelesaikan perkara gugatan wanprestasi di lembaga keuangan.

2. Bagi para pihak yang akan melangsungkan pembiayaan di lembaga keuangan sebaiknya untuk lebih mengenal dirinya sendiri apakah sanggup membayar secara bertahap atas keinginan untuk mengambil pembiayaan tersebut, serta bagi pihak bank sebaiknya lebih untuk memperhatikan penerapan prinsip kehati-hatian dalam memberikan pembiayaan.

3. Bagi pihak bank seharusnya lebih mengedepankan penerapan prinsip kepercayaan (fiduciary principle) dalam kegiatan operasional, dan juga harus melaksanakan prinsip pengelolaan yaitu prinsip kehati-hatian (prudential banking) terhadap nasabah yang akan melangsungkan perjanjian pembiayaan di bank tersebut.

4. Bagi Lembaga Peradilan dalam hal ini Pengadilan Agama sebagai salah satu institusi yang menyelesaikan perkara wanprestasi, harus lebih memperhatikan kepentingan para pihak yang berperkara dan dalam proses pembuktian supaya pihak-pihak yang berperkara merasakan keadilan dalampenyelsaian perkaranya.

5. Bagi Mahkamah Agung, diharapkan kejelasan dan penegasan terkait kewenangan absolut Peradilan Agama dalam hal sengketa ekonomi syari'ah antara lain sengketa perbankan syariah sebagaimana pasal 55 UU No.21 Tahun 2008 tentang perbankan syariah. Karena secara teori, penyelesaian sengketa perbankan syariah masih terdapat peluang bagi lembaga Peradilan yang lain misalnya Peradilan Umum, padahal ini terkait praktek syari'ah

6. Bagi Mahkamah Agung, agar dilakukan peningkatan kapasitas hakim peradilan agama terkait pengetahuan ekonomi syariah karena hal tersebut dianggap sangat penting bagi para hakim dalam memutuskan perkara sebagai penegak 
keadilan.

7. Senantiasa ditingkatkan sosialisasi UU No.3 Tahun 2006 tentang Peradilan Agama dan kewenangannya, agar tidak ada pelaku Bisnis Syari'ah yang belum tahu tentang keberadaannya, bahkan masih terdapat klausul Pengadilan Umum untuk menyelesaikan perkara Perbankan Syari'ah, padahal sengketa perbankan syari'ah serta ekonomi syari'ah yang lain adalah kewenangan absolut Peradilan Agama berdasarkan UU Nomor 3 Tahun 2006. 


\section{DAFTAR PUSTAKA}

Carl Joachim Friedrich, Filsafat Hukum Perspektif Historis (Bandung: Nuansa dan Nusamedia, 2004)

Shihab, M. Quraish. 2001. Wawasan Al-Quran: Tafsir Maudhu'I atas Perbagai Persoalan Umat. Bandung: Penerbit Mizan.

Rawls, John., 1990. A Theory of Justice, London, Oxford, New York: Harvard University Press.

Nurjaeni, Kosep Keadilan Dalam Al-Qur'an, www.duriyat.or.id/artikel/keadilan.htm, diakses pada tanggal 28 Mei 2017.

Jaih Mubarok, Hukum Ekonomi Syariah Akad Mudharabah (Bandung: fokusmedia, 2013).

Juhaya S Pradja, Ekonomi Syariah (Bogor: Pustaka Setia, 2012).

\section{A. PERATURAN PERUNDANG-UNDANGAN}

- Undang-Undang RI Nomor 3 Tahun 2006 tentang Penradilan Agama Undang-Undang RI Nomor 7 Tahun 1989 tentang Peradilan Agama Undang-Undang RI Nomor 21 Tahun 2008 tentang Perbankan Syariah. Undang-Undang RI Nomor 48 Tahun 2009 tentang Kekuasaan Kehakiman Undang-Undang RI Nomor 50 Tahun 2009 tentang Peradilan Agama Kitab Undang-Undang Hukum Perdata. PERMA Nomor 02 Tahun 2008 Tentang Komplikasi Hukum Ekonomi Syariah Departemen Pendidikan dan Kebudayaam, Kamus Besar Bahasa Indonesia 